\title{
Improving Students' Speaking Skill Through Predicting With Storytelling at Grade XI/Social Science SMAN 10 Bukit Barisan Pekanbaru
}

\author{
Djoni \\ STIBA Persada Bunda Pekanbaru \\ E-mail: joniramli26@gmail.com
}

\begin{abstract}
Speaking skill is one of the important skill in learning English. However, the students speaking skill of grade XI/ Social Science SMAN 10 Bukit Barisan Pekanbaru don't achieve the students' speaking minimum standard score as required by curriculum. This problem might be caused by the teacher techniques in teaching. This research is aimed at determining the effectiveness of predicting with storytelling in improving the students' speaking skills. Besides this research is also to identify the factors which influence the improvements of the students speaking skill through predicting with storytelling. This research was a Classroom Action Research which consited of three cycles. Each cycle involved planning, action, observation and reflection. The instrument used in this research were observation and speaking test. Observation was aimed to know both students and the teacher activities during the process of teaching and learning. Meanwhile speaking test means to evaluate the students speaking skill at the end of each cycle. At the first cycle, it was found that the average score of the students' speaking test is 59. Because of this research is not satisfied yet, so the research was continued the second cycle. Then, in cycle two it was found that the average score of the students speaking test is 66 . Some factors that might be caused the improvement of the students speaking skill are materials, media, activities, classroom management, and teacher's approach. To get better result and to make the students more familiar with predicting storytelling so the third cycle was done. Finally, it was found that the average score of students' speaking test is 75. Based on the finding above, it is concluded that predicting with storytelling is an effective way in improving the students' speaking skill.
\end{abstract}

Key words: Speaking skill, Predicting, Storytelling. 


\section{INTRODUCTION}

Speaking English as a foreign language (EFL) for students is not easy. Based on the researchers' observation in his room the students get problems to practice speaking English. There are at least four problem view points which make the students have poor ability in speaking.

First, the students' speaking skill is unsatisfactory or low from the minimum standard score achievement. To get high scores in Senior High School is minimum standard score achievement. The students speaking minimum standard score achievement is seventy. Meanwhile, the students speaking grade point average achievement was sixty five percent.

Second, the English speaking topics are not interesting. The domination of oral English teaching materials in schools are focused on situational and communicative function which aims at enabling students to cope in the target language. However, the students often complain that they have been repeatedly asked to introduce their families, schools, favourite food and drink, transportation, and hobbies. They also make dialogues on topics such as job interviews, meetings visitors, or shopping. These "practical" tasks and situations provide little space for the students to create their own creation. Therefore, dialogues on these situational topics are hard to develop in depth and width. Students tend to loose interest in what they learn if they find they make little progress.
Third, the students don't have high motivation in speaking. One aspect that influenced the students' low motivation is not confident. They are afraid if they used English to speak in the classroom, their friends would laugh at him. They fear of making mistakes. This situation makes the students discomfort to use English to communicate. Every time their teacher asks them to speak, they can not do it well. They freeze when their name are called to speak. Therefore, the students worry influences their performance.

Fourth, the teaching techniques used by the teacher in teaching speaking are less variation. For example, through communicative games. One student write a word on a paper and others guess what word she or he writes by giving some questions. The teacher does not use the strategy prediction to focus on and recall the events in a story. The teacher who lack of knowledge and experience in applying the strategy in teaching speaking is one of the causes of the difficulties of the students to speak English happily.

Based on the background of the problem, there are some problems that can be identified. First problem, the students speaking skill is unsatisfactory or low from the minimum standard score achievement. The second problem, the English speaking topics are not interesting. The third problem, the students have low motivation in speaking learning process. The last problem, in teaching English especially in speaking are the teaching techniques used by the 
teacher in teaching speaking is less variation.

Based on the identification of the problem above, the researcher focused this research on technique of teaching speaking. The technique is predicting with storytelling.

This research is done to answer the research question as follows.

1) To what extent can be predicting with storytelling improve students' speaking skill at grade XI SMAN 10 Bukit Barisan Pekanbaru?

2) What factors influence the changes of students speaking skill through predicting with storytelling at grade XI SMAN 10 Bukit Barisan Pekanbaru?

The purpose of the research is to determine whether predicting with storytelling can improve students' speaking skill at grade XI SMAN 10 Bukit Barisan Pekanbaru. Moreover, the purpose is also to explain the factors that influence the changes of students' speaking skill through predicting with storytelling.

First, the research is useful for teacher to improve their techniques and overcome the problems that they encounter in teaching speaking, especially about predicting with storytelling.

Second, the result of this research can be useful for educators who has responsibility to plan and develop teaching speaking. Moreover, this research can be as the input for institutions and planning and developing curriculum.

1. Speaking skill is the ability to speak and to communicate in English language.

2. Predicting with storytelling involves thinking of the kind of words, phrases or information based on students background knowledge or schemata and link the new knowledge with the knowledge they already possess they encounter during the task by telling the story in an interesting way.

\subsection{Speaking Skill}

There are so many concepts of speaking skill defined by theoreticians. According to Fulcher (2003:22) speaking is an ability that is taken for granted, learned as it is through a process of socialization through communicating and also speaking is the verbal use of language to communicate with other. Then Brown (2004:140) states that speaking is a productive skill that can be directly and empirically observed. Furthermore, Solahuddin (2008:16) also defines that speaking is the ability to speak or communicate ideas, thoughts or issues in English.

Based on the above defenitions, the researcher concludes that speaking is the ability to speak and communicate in English language.

The goal of a speaking component in a language class is to encourage the acquisition of communicative skills and to foster real communication in 
and out of the classroom. Subsequently, the teacher should touch grammatical structures in the speaking teaching and learning process and integrate them to other skills.

In applying the predicting with storytelling in teaching speaking requires the students background knowledge. The students will use it to understand the story that they are going to understand and talk about it.

\subsubsection{Background Knowledge}

Background knowledge is the prior knowledge of someone to understand a text. It is highly needed by the students to comprehend the text easily. Therefore, the teacher needs to elicit the students background knowledge when teaching reading or inviting the students to talk about a topic.

Nunan (2003:74) stated that background knowledge includes all of the experiences that a reader carry to a text: life and educational experiences, knowledge of how organized a text, knowledge of how someone first and second language works and cultural background knowledge.

Based on explanation above, the researcher conclude that background knowledge is the students prior knowledge which the teacher elicits to bring the students to the topic or story that they are going to comprehend. To activate the students background knowledge, the teacher can use prediction and schemata.

\subsubsection{Schemata}

Schemata is a theory to understand a text by using background knowledge and organized it into patterns which are constructed from the experience.

Nunan (2000:68) states that schemata theory is the knowledge which we think in our head and organized into connected patterns. These are constructed from our last experience and guide us to the new experiences. They also possible to make prediction about experience in a given contex.

Futhermore, Stott (2001:1) states that schemata theory is the process of readers in combining their own background knowledgewith the information in a text to comprehend it. It means that in teaching reading to the students, applying schemata theory will help them to understand the text.

Then, Sigma (2002:1) defines that schemata is the kind of mental representation for getting knowledge. Furthermore, he said that schemata theory was applied soon to understand the reading process and it served an important bottom-up approaches in reading.

In the line of this idea, Ajideh (2003:4) defines that a schemata is an unreal mental structure for sending generic concept kept in memory. It is a type of framework, or planning or script. He also gives an example that when we encounter something again such as restaurant, we can generalize 
restaurant with our restaurant experiences.

In the line of this idea, Littlewood (2009:1) states that the concept of the schemata is often used as a way of describing the mental structure by organizing our last experience, to do our continuing experience, and build up our expectation.

\subsection{Predicting}

Predicting is kind of strategy in understanding the text. It can be done before or during the process of reading. It needs the students' background knowledge of the topic or story and they can predict about the story.

There are some definitions from some experts about predicting as follows:

Oczuks (2005:3) states predicting involves previewing the text to anticipate what will happen next. The thinking process involved in predicting assist students in making meaning. In order to do this successfully, students must activate relevant background knowledge that they possess on the topic. One student has made a prediction, they have a purpose for reading to confirm or disprove their prediction.

\subsection{Storytelling}

Storytelling often used by the teacher to develop speaking skill. It is an interesting activity that improve the students' motivation to speak and to read as well.
Skvortsov (2007:1) states that storytelling is the way someone tells a story in interesting way. The elements of a successful story are first, protagonist. The most important character in the story. Second, the story must involve a change of values. Third, an interesting story always causes emphaty and fourth, the events are very important.

Wikipedia (2009:2) states that story a description of a chain of events and a piece of fiction told or written in a prose or verse.

Based on the experts findings, the researcher concludes that first, storytelling is the way someone tells a story in an interesting way. In strorytelling, the interaction between teller and listener is immediate, personal, active and direct. Second, characteristic of the story is a chain of events, a piece of fiction, interesting, amuse the hearer and increase knowledge.

\section{Evaluation of Speaking Skill}

To evaluate the achievement of the accomplishment of speaking skill, students perform their proficiency based on the characteristics of the speaking test. The criteria of assessing speaking test are:

Subsequently, Brown (2004:141) states that the basic speaking test are (1) imitation is the ability to imitate the sounds of the words, phrases or utterances. (2) Intention is the ability to speak through the shorter answers or responses according to the structures of sentences and the accurate phonology. 
(3) Response include the interaction test and comprehension test. (4) Interaction is the ability to put across the ideas through the complex interaction and multiple participants. (5) Extention (monologue) includes speech oral presentation and story telling.

Based on the experts' statement above, the accurate evaluation model to examine the ability of students' speaking skill through the sociolinguistic approach is the extensive types of dialogue.

Based on the explanation above, the researcher conclude the criteria of speaking evaluation. This criteria will use as speaking test indicators.

At last Yasin (2010:77) states that the researcher needs three sheets to know the relation between quantitative data and qualitative data. Three sheets consist of the process of teaching and learning speaking, observation sheet and the mark of indicator. To complete this research the researcher also used this observation sheet.

In order to support this research, there are several previous studies which have been conducted by some researchers. For example Ali Akbar (2008) has conducted a research about Improving Students' Speaking Skill through Teaching Good Language Learner Strategies at SMA Negeri 1 Lareh Sago Halaban Lima Puluh Kota Regency. He concluded that teaching good language learner strategies of speaking could improve the skill of the students to speak English.

\section{METHOD}

This research is a classroom action research. The action research in the classroom is a tool for teacher to solve their problem in their classroom. It is also aims to increase the teacher's understanding of classroom teaching and learning.

Gay and Airasian (2000:593) states that action research is a process in which the individual or several teachers collect evidience and make decision about their own knowledge, performance, belief and effects to understand and improve them. Furthermore, Johnson (2005:21) states that action research can be defined as process of studying a real school situation. At last, Madya (2006:51) states firmly that classroom action reseaarch is collaborative research done by researchers through collaboration.

From the expert statement, this can be concludes that action research is a research done by the teachers toward their students in the classroom and cooperate with the same other teachers and aims at improving learning quality in the class.

Based on statement researcher applied a collaborative action research. It means between researcher and teacher work together to solve their problem in teaching speaking or improve their students' speaking skill through Predicting with Storytelling. They shared together in doing research to change their problem become well. 


\subsection{Participants and Setting}

The classroom action research took place at SMAN 10 Bukit Barisan Pekanbaru. The time for each meeting was 80 minutes in a week. The researcher chose this class because of two reasons. The first was the students have low in speaking skill, and the second was because the researcher knew the principal in this school. Then, the researcher continued to the second or third cycles. Finally, the data that have been gotten was evaluated and reflected by the researcher and the observer.

Then, the activities in every cycle were as follows:

1. Plan

Here is an activity that was done by the researcher and his collaborator during the research.

1. Designing the lesson plan

2. Select the standard competence, based competence and indicator done in the research based on the students' problem in the classroom

3. Providing some topics that would be discussed. The topic consisted of the beginning of the story.

4. Providing some speaking media and aids.

5. Providing speaking test which would be given at the end of the cycle.
6. Providing observation checklists, observation guide and field notes for the collaborator.

2. Action

In this section, the researcher performed an action done based on the plan made on the planning.

3. Observation

During the action, the collaborator helped the researcher. The collaborator would observe the teaching and learning process and the factors influence the change of students speaking skill through research checklist, field note and interview.

4. Reflection

The researcher collected the data, evaluated and then analyzed it. For quantitative, the researcher would evaluate the students through the result of their task and test by using observation checklist.

The researcher collected quantitative data by doing interview. In this case, the researcher knew the factor influence the change of students speaking skill through observation. Then, the researcher analyzed the students activities during teaching and learning process.

\subsection{Instruments}

They key instrument in this research was the researcher himself. He was involved in the field activity in each cycle. In collecting data of the 
research, the researcher used the instrument as follows:

Furthermore, the researcher used speaking task and test for quantitative data. He also use observation sheet and interview for qualitative data. They describe as follows:

\subsubsection{Quantitative data.}

The data from quantitative was taken from students speaking task and test. Students speaking task was analized by using observation checklist of speaking task, observation checklist of prediction and observation checklist of the story.

\subsection{Technique of Data Collection}

As the previous statement above, the researcher would collect the data in two ways:

\section{Quantitative Data}

Quantitative data was to know what extent predicting with storytelling can improve the students speaking skill. In quantitative data, the researcher would collect the data through students speaking task and test. Students speaking task was taken from students activity in predicting the story and present their storytelling in meeting 1 to meeting 3 in every cycle. Students speaking test was taken in the end of each cycle. Next, the researcher analyzed the data by using the indicators of speaking. The indicators of speaking based on the speaking rubric guide. Furthermore, the researcher was going to use Brown indicators in speaking in this research (Brown, 2004:172). In scoring the students speaking skill, the researcher would get in percentage.

\section{Qualitative Data}

Qualitative data is to know what factors influence the changes of students speaking skill through predicting with storytelling. In qualitative, the researcher would collect the data through observation and interview. Observation was taken from checklist and field note during teaching and learning process. Interview was taken when the researcher asked the students about their situation and condition in the process of teaching and learning.

\subsection{Technique of Data Analysis}

The researcher could be analyzed the data in this research in two ways:

\section{Quantitative}

The students task in meeting 1 to meeting 3 in every cycle and the students test at the end of each cycle were interpreted by quantitative analysis based on numbers and percentages.

\section{Qualitative}

Qualitative analysis was to explain the process of teaching and learning process. In qualitative, the researcher would analyzed the data about observation and interview. The data were analyzed to know what factors influence the changes of students speaking skill through predicting with storytelling. 


\section{FINDINGS AND DISCUSSION}

\subsection{Findings}

This chapter provided an analysis of the data which collected through observation, field note and interviews to answer the formulation of the problem.

1) To what extent could be predicting with storytelling improve students' speaking skill at class XI / Social Science SMAN 10 Pekanbaru?

2) What factors influences the changes of students speaking skill through predicting with storytelling at class XI/Social Science SMAN 10 Pekanbaru?

The data obtained from observation and field note were analyzed to identify students active participation in speaking class. The data from interview were analyzed to comprehend the students' responses in teaching and learning

The picture was a little bit small, so the students who sat on the back could not see the picture clearly. Therefore, they could not involved much in answering teachers question during activating background knowledge.

Based on the data in the observation and the weakness that the researcher found in the first cycle, he concludes that the students' indicator of speaking evaluation were not satisfied yet because the students had limitted vocabualry. The students often opened dictionary to gain the new words. It could waste the time. So, they had few times to speak with their friends. Next, the picture as a media was a little bit small. The researcher hoped that by applying the same strategy to the different topic in the second cycle, these problem could be solved. Therefore, there should be some revising for the next cycle to improve the learning process. So that the students' speaking skill improved.

\subsection{Discussion}

Besides improving the students' speaking skill, other findings found during the application of the predicting with storytelling are as follows. The first is the students enjoy in studying English. The observation from the researcher and collaborator show that the students are happy to do prediction and retell the story with their own words. Then, the second is the students are confident to use English during interaction in the classroom. They are eager to tell their ideas in predicting the story, eventhough sometimes they mix English with their mother language.

Meanwhile, to answer the second question,"What factors influences the changes of the students' speaking skill through predicting with storytelling at class XI/SMAN 10 Bukit Barisan Pekanbaru, it could be identified from the data of field notes and observation checklist which were written by the researcher and collaborator during the process of teaching and learning. They got several aspects that improve the students' speaking skill. They are as follows: 1) Material could improve the students eagerness to speak. By having interesting materials the students had 
willingness to have discussion and enjoyed storytelling.

\section{CONCLUSIONS}

\subsection{Conclusion}

Based on the result of the research or finding. It can be concluded that:

1. The implementation of predicting with strorytelling in improving the students' speaking skill at class XI/Social Science SMAN 10 Bukit Barisan for three months had been successful. It is found from the data findings that predicting with storytelling improves students' speaking skill.

The factors that influence the changes of students' speaking skill are:

\section{a. Materials}

Materials improve the students' eagerness to speak. By having interesting materials, the students have willingness to have discussion and enjoy storytelling.

\section{b. Media}

Media like pictures improve the students' motivation to speak in speaking class. Media is an effective way to develop the students background knowledge to the topic given. It helps the students to say words or ideas by answering the teacher's questions based on the picture given.

c. Activities

$$
\text { By doing predicting activities }
$$

the students are eager to speak because they are given a chance to activate their background knowledge to the story given.

d. Classroom Management Classroom management improves students to speak. The researcher controls and helps the students' activities during the process of doing the task in group discussion.

e. Teacher's Approach

Teacher's approach is one factor that motivates students to speak in applying predicting with storytelling.

\subsection{Implication}

Based on the conclusion above, there are two kinds of implications of this research. They are: The use of predicting with storytelling is one of the alternative strategy that can be applied in teaching to improve students' speaking skill. The teacher needs more knowledge to handle classroom in teaching and learning process by activating students background knowledge in order to make the process of learning and teaching enjoyable.

\subsection{Suggestions}

Based on conclusion and the weaknesses found in applying the predicting with storytelling to improve the students' speaking skill, it is suggested to the teacher to do some points as improvement of the weaknessess emerged during the research 


\section{REFERENCES}

Ajideh, Parviz. 2003. Schema TheoryBased Pre-Reading Tasks: A Neglected Essential in the ESL Reading Class. Iran. English Department of Tabriz University.

Brown, Douglas. H. 2004. Language Assessment. Principle and Classroom Practice.San Fransisco: San Fransisco State University.

Fulcher, Glenn. 2003. Testing Second Language Speaking. Malaysia. Person Education limitted.

Gay. L.R and Airasian, Peter. 2000. Educational Research. Competities for Analysis and Application. Ohio: Late of Florida University.

Johnson, Andrew p. 2005. A Short Guide to Action Research. Boston. Pearson Education inc.

Littlewood, William. 2009. Adapting Classroom Schemata. Retrieved on August 25, 2009 at Sunzil.lib.hku.h/hkjo/view/5/50 0058.pdf.

Nunan, David. 2000. Language Teaching Methodology. A texbook for teachers. Macquaire University.

Oczucks. 2005. Reciprocal Teacing. Florida Department of Education. Retrieved on June 16 , 2009. ahttp:/forpd.ucf.edu./strategiest/s trateciprocalteaching1.html.
Scvortsov, Andrey. 2007. Storytelling. Mercator Group. Retrieved on June 16, 2009 at http:/eng.mercator.ru/articles/art icle.php?articleID=51.

Stott. 2001. Helping ESL Students Become Better Readers: Scheme Theory, Applications And Limittations. Japan. The Internet

TESL Journal. Vol. VII. No.11. Retrieved On August 6, 2009 at http://iteslj.org/Articles/StottSchema.html.

Sigma, Six Lean. 2002. Learning Theory: Schema Theory. Retrieved on August 25, 2009 at http://www.answers.com/topic/l earning-theory-schema

Solahuddin, M. 2008. Kiat-Kiat Praktis Belajar Speaking. Jogjakarta: Diva Press.

Wikipedia, Hutchinson. 2009. Story. Houghton. Miffin Company. Retrieved on June 16, 2009 at http://www.thefreedictionary.co m.story. 
